\title{
The Impact of Academic Resilience on Academic Performance in College Students During the Covid-19 Pandemic
}

\author{
Ike Dwiastutiti,2*, Wiwin Hendriani¹, and Fitri Andriani ${ }^{1}$ \\ ${ }^{1}$ Psychology, Universitas Airlangga, Surabaya, Indonesia. \\ ${ }^{2}$ Psychology, Universitas Negeri Malang, Malang, Indonesia. \\ ORCID \\ Ike Dwiastuti; https://orcid.org/0000-0001-7806-3106
}

Corresponding Author: Ike Dwiastuti; email: ike.dwiastuti2020@psikologi.unair.ac.id

\section{Dates}

Published 28 January 2022

Publishing services provided by Knowledge E

(c) Ike Dwiastuti et al. This article is distributed under the terms of the Creative Commons

Attribution License, which permits unrestricted use and redistribution provided that the original author and source are credited.

Selection and Peer-review under the responsibility of the ICoPsy Conference Committee.
Abstract. The COVID-19 pandemic has become a tough challenge for college students, especially in maintaining their achievements. The purpose of this study was to determine the impact of academic resilience on college student academic performance and to investigate the risk and protective factors of academic resilience. The participants included 221 active college students in their $4^{\text {th }}$ or $6^{\text {th }}$ semester, from scientific and technology or social humanities study groups. This was a quantitative study and data were collected using the Indonesian version of ARS 30, a form to collect demographic information, scores from the achievement index semester (S-GPA), and cumulative achievement index (GPA) scores. The results of the descriptive statistical analysis showed that the most influential risk factor was problems related to the academic process, namely the adjustment of education. Another risk factor was economic conditions, as many of the students experienced economic difficulties during this pandemic. Protective factors included the students' effort and ability. The results of linear and logistic regression analyses showed that academic resilience affected academic performance. The findings indicated that students with high academic resilience had a 1.73 times higher odds of maintaining and improving academic performance compared to the other students. The implication of this research is to encourage universities to make policies that can increase students' academic resilience, especially during a pandemic. Further research is recommended to further examine risk and protective factors during the pandemic.

Keywords: academic resilience, academic performance, college students, logistic regression, Covid-19 pandemic

\section{Introduction}

Students will face more tough challenges and competition at higher education levels (1)(2). Increased challenges and competition occur in the academic and non-academic fields. This happens because the subject matter is getting more difficult, there are more assignments, the competition for academic achievement is getting tighter, the school capacity is getting bigger, the socio-economic background of students is getting more diverse, and the social relations among students, and between students and teachers 
are getting more impersonal. In higher education, students face increasingly tough academic demands, for example at the master's level they will face the challenge of writing articles for reputable journals (3), and at the doctoral level are required to be scientists who produce scientific findings (4). Currently, students feel more burdened to succeed in college, compete for jobs, and make a lot of money when they graduate.

Challenges at the university level increased during the COVID-19 pandemic. The challenges are not only experienced by students, but also by teachers and even by educational institutions. The pandemic condition causes economic problems at the nation and individual level, marked by the economic recession experienced by various countries, including Indonesia (5). The recession also had an impact on the family economy, because many entrepreneur lost the customers and employees were laid off (6). There are also health problems, and the loss of family members, as well as mental health. The results of the literature review of previous research indicate that students experience stress ranging from mild, moderate to high levels during the pandemic, and can be said to experience low subjective well-being (7).

The COVID-19 pandemic has have a major impact on various aspects of education (8). In general, the impact of the economic recession on students is difficulty in paying for education, considering changing education or career goals, managing limited resources according to priorities, and feeling hopeless and helpless (9). In addition, there has been a significant change in learning methods to adapt to the pandemic situation, namely study from home (SFH) (7). SFH is carried out utilizing online learning. This is applied because the government implements a social distancing strategy during the pandemic to reduce the spread of the virus $(10,11)$. This change makes all parties have to adapt, but not all of them can do well $(12,13)$. Students experience various obstacles related to online learning.

When students face acute and chronic obstacles, such as during the COVID-19 pandemic, students need to have academic resilience capacity (8). Previous research has proven that the academic resilience capacity of students can affect academic satisfaction and academic performance (14). So, it is important to research more about academic resilience during this pandemic. Researchers have different definitions of academic resilience, it is as a capacity $(15,16)$, as a process $(17)$, and some define it as result or outcome (18). This difference causes differences in the measurement of academic resilience in individuals. Research that emphasizes academic resilience based on capacity generally uses an instrument in the form of a Likert scale. Whereas research that defines academic resilience as an outcome will measure based on the two criteria, that is the existence of a difficulty and the existence of excellent academic performance. 
In previous studies, risk factors that affect academic resilience include anxiety, stress, trauma, social barriers, negative friends, individual conflict attitudes, low satisfaction in relationships with family, having family responsibilities, refusing school, low commitment to school, have a loan, and work full time (19-25). Protective factors are divided into internal and external factors. Internal factors are related to the strengths that exist within the individual, such as perceived academic competence (26), self-efficacy (27), self-motivation and goal-setting (28), and persistent (29). External protective factors are related to positive things from outside the individual that has a positive effect on students' academic performance, such as the role of parents (30), the role of educational institutions (schools) (31), the role of the teacher (32), and the role of friends (33).

This study aims to explore the risk factors and protective factors that affect academic resilience during the pandemic. The next objective is to find out whether there is an effect of capacity-based academic resilience on outcome-based academic resilience and academic performance in college students. Previous research on academic resilience was conducted in various contexts, including the context of academic stress, violence, immigration, and socioeconomic status. In this study, we will focus on the context of the COVID-19 pandemic, because the challenges and obstacles at this time are felt to be acute and chronic, and almost all students are affected. The results of this study will contribute to student academic achievement during the pandemic and provide guidelines for increasing academic resilience for students by institutions.

\section{Literature Review}

\subsection{Ecological Theory and Positive Psychology}

Factors that influence individual behavior include many factors. Efforts to understand human development in cognitive, socio-emotional, and behavioral aspects, need to take into account the complexity of the interaction of the individual's internal role and the role of the environment (2). The ecological theory emphasizes the influence of the environment on individual development.(34) proposed an environmental system perspective in individual development consisting of microsystems, mesosystems, ecosystems, macrosystems, and chronosystems (34).

The perspective of positive psychology emphasizes the exploration of characteristics that reflect the goodness or strength of humans in optimizing human functions (35). Optimal functioning is facilitated through individual positive characteristics and good behavior as a positive process. A positive process will result in individual and collective 
well-being, which is a positive outcome. The expected result of positive psychology is an optimal function, namely happiness, and well-being.

This study will explore individuals through these two perspectives. Human development cannot be separated from the social and physical environment, so it will consider internal factors and external factors of the individual. External factors are involved especially at the microsystem level. Meanwhile, internal factors will emphasize the things that become individual strengths. This is in accordance with the theoretical framework of positive psychology.

\subsection{Psychological Resilience and Academic Resilience}

Resilience and academic resilience are closely related. Academic resilience is a concept rooted in psychological resilience (15). However, psychological resilience emphasizes the creation of psychological well-being through adaptation to the problems encountered, while academic resilience emphasizes academic achievement despite facing severe obstacles (17). Novotny (2011) explained that the term resilience is used together with descriptive adjectives, so it will be more accurate to discuss resilience in certain fields, such as academic resilience (36).

Resilience is the ability to develop, mature, and be able to increase self-competence in dealing with adverse conditions, including biological and environmental constraints (37). Resilience theory believes that almost all young people have an innate and natural capacity for resilience that can develop positively and healthily (17). Resilience includes the ability to be able to bounce back or return to its original state. Cassidy (2016) argues that resilience is a psychological construct that explains success despite adversity and is considered an asset in human characteristics, which describes the ability to bounce back, to overcome obstacles (15).(38) concluded from various experts that psychological resilience is an individual's ability to think and act when faced with difficult situations, resulting in three typical conditions of resilience, e.g. better results even in high-risk conditions, able to survive under threats, and being able to recover from trauma (38).

Academic resilience has several different definitions. (16)defines academic resilience as a student's capacity to cope with acute or chronic problems that are considered to be the main disturbance in the student's educational process (16). That definition is followed by (15) which emphasizes the individual's capacity to face academic challenges (27). Some researchers define academic resilience as an outcome, namely the existence of academic achievements achieved by students with high-risk backgrounds (18). The other definition of academic resilience is to emphasize a process of dealing with 
high-risk situations through the education system and producing excellence academic achievement (17).

This study will use the definition of capacity and definition of outcome. The definition of capacity will be used to determine an individual's potential to survive, thrive and improve in educational and academic settings. While the definition of outcome will be used to determine the actual achievement of this student. The instrument used will adjust to the definition used.

\section{Method}

This study uses a quantitative approach with a survey method. The survey method makes it possible to explore things that cannot be observed, such as thoughts, feelings, and attitudes (39). The dependent variable in this study is outcome-based academic resilience. While the independent variable is the capacity-based academic resilience.

\subsection{Participants}

Participants are active undergraduate students (four-year program), second and third years, at one of the public universities in Malang, Indonesia. Active students refer to the status of students who register and make study plans. Participants were selected using a convenience sampling technique, that is by distributing the research instrument through social media and the researcher's group messenger, in March until April 2021. Instruments are arranged in an electronic form (google form). Data can be collected from 311 participants, but 80 do not meet the criteria, so there are 221 participants whose data will be analyzed. Participants consisted of 45 men (20.4\%) and 176 women (79.6\%). They are spread in groups of 68 science and technology studies (30.8\%), 153 social humanities studies (69.2\%), the fourth semester is 94 (42.5\%), and the sixth semester is 127 (57.5\%). On the status of tuition fees, there are 35 scholarship awardee (15.8\%) and 186 regular students $(84.2 \%)$.

\subsection{Data Collection Instruments}

There are several kinds of instruments used, that is demographic forms (include academic performance self-report), and academic resilience scales. 


\subsection{Demographic Data}

A demographic form asking about the status of tuition fees, parents' last education (father), subjective assessment of the ability to adapt to online lectures, risk factors being faced, and protective factors that help the education process, will be recorded using the demographic aspect form. Subjective assessment is an evaluation carried out by the participants themselves regarding their condition. In addition, the demographic form also explores data on gender, age, and a group of fields of study.

\subsection{Academic Resilience Capacity}

Academic resilience capacity is the potential ability of students to be able to survive and improve achievement despite facing severe problems or the presence of severe risk factors. This capacity will be measured using the Academic Resilience Scale (ARS 30) (15) which has been adapted into the Indonesian language and culture by $(15,40)$. ARS 30 initially consisted of 30 items with three aspects, namely, perception, reflecting, and affect. ARS-30 has psychometric properties of reliability Cronbach's alpha $=0.90$. In the Indonesian version of ARS, there are 24 valid items, 6 of which have fallen. Convergent validity with CFA analysis on 24 items, the results obtained that CR perseverance $=$ 0.988 , reflecting $=0.989$, and Affect $=0.917$. Students who have a high academic resilience capacity score are said to have the potential to succeed in facing difficulties. Meanwhile, students who have a low academic resilience capacity score are said to be at risk of not being able to overcome the problems they are facing.

\subsection{Academic Performance}

Outcome-based academic resilience is assessed based on the cumulative achievement index (GPA) score and whether there is a change in the semester achievement index (S-GPA) between the even semester 2019/2020 and the odd semester 2020/2021. From the change of S-GPA, each participant was categorized as increasing, constant and decreasing. Achieve high outcome-based academic resilience is that students who can maintain (constant) and who can improve (increasing) the semester achievement index (S-GPA), while experiencing a decline (decreasing) in the S-GPA are classified as low outcome-based academic resilience. This criterion is following the definition of the outcome, namely the existence of academic achievements achieved by students 
despite experiencing obstacles $(17,18)$. Academic achievement is based on participants scores or overall grades or achievement index.

\subsubsection{Data Analysis}

The analysis in this study will be divided into several statistical techniques. The analysis to determine the risk factors and protective factors according to the subjective assessment of students during this pandemic will use descriptive statistics so that it will display frequency information. The analysis to prove whether there is an effect of capacity-based academic resilience on outcome-based academic resilience will use the logistic regression technique. And for further exploration of whether there is an effect of academic resilience capacity on academic performance, we will use a simple linear regression technique. Meanwhile, for the comparison of differences in academic resilience capacity and academic performance in terms of demographics, the ANOVA technique will be used.

\section{Result and Discussion}

\subsection{Result}

\subsubsection{Risk factors and protective factors based on student assessment}

The following are the results of a survey of risk factors that are the main problems, as well as protective factors that affect the smooth process of students in academics and education, especially during the COVID-19 pandemic, as follows:

The participants subjectively assessed the risk factors that were the main obstacles for students in the academic and educational context during the COVID-19 pandemic. Participants can choose more than one answer and can add other factors that are considered relevant. The survey results are summarized in Table 1, where there are a total of 306 answers from 221 participants, so it can be said that some of the participants answered more than one. Academic problems are problems that are experienced by many participants, 65 (21.2\%) economy problem, 41 (13.4\%) problem with family, 39 (12.7\%) problem environmental adjustment, 22 (7.2\%) problem with friends, 12 (3.9\%) personal problems, 9 (2.9\%) problems with the faculty, and 4 students feel they tend not to have problems (1.3\%). 
TABLE 1: Risk factors and protective factors during the COVID-19 pandemic

\begin{tabular}{|c|c|c|c|c|c|}
\hline Risk factor & Amount & Percentage & $\begin{array}{l}\text { Protective } \\
\text { Factor }\end{array}$ & Amount & Percentage \\
\hline $\begin{array}{l}\text { Academic problems } \\
\text { (process and } \\
\text { coursework) }\end{array}$ & 114 & $37.3 \%$ & Self-effort & 172 & $36.9 \%$ \\
\hline Economy problem & 65 & $21.2 \%$ & Self ability & 115 & $24.7 \%$ \\
\hline $\begin{array}{l}\text { Problems with } \\
\text { Family }\end{array}$ & 41 & $13.4 \%$ & Friends help & 73 & $15.7 \%$ \\
\hline $\begin{array}{l}\text { The problem of } \\
\text { adapting to the } \\
\text { environment }\end{array}$ & 39 & $12.7 \%$ & $\begin{array}{l}\text { Family/ parents } \\
\text { help }\end{array}$ & 72 & $15.5 \%$ \\
\hline $\begin{array}{l}\text { Problems with } \\
\text { Friends }\end{array}$ & 22 & $7.2 \%$ & $\begin{array}{l}\text { Faculty } \\
\text { assistance }\end{array}$ & 31 & $6.7 \%$ \\
\hline Personal Problem & 12 & $3.9 \%$ & & & \\
\hline $\begin{array}{l}\text { Problems with } \\
\text { Faculty }\end{array}$ & 9 & $2.9 \%$ & Other & 3 & $0.6 \%$ \\
\hline Other & 4 & $1.3 \%$ & & & \\
\hline Total & 306 & $100 \%$ & Total & 466 & $100 \%$ \\
\hline
\end{tabular}

Participants were also assessed subjectively about the protective factors that influence student success in academic and educational contexts during the COVID-19 pandemic. Participants can choose more than one answer and can add other factors that are considered relevant. The survey results are summarized in Table 1, where there are 466 answers given by 221 participants, so it can be concluded that the average participant answered more than 2 which is considered a protective factor. The protective factor that plays the main role according to students is the existence of self-effort as much as 172 (36.9\%), followed by self-ability as much as 115 (24.7\%), friend assistance as much as 73 (15.7\%), parent assistance as much as 72 (15.5\%), faculty assistance as much as 31 (6.7\%), and there were other factors as much as 3 (0.6\%).

\subsubsection{Student academic resilience capacity-based on demographic aspects}

The results of the descriptive analysis show that there are slight differences in academic resilience capacity between demographic categories:

The results of the descriptive analysis show that there are differences in student academic resilience capacity scores on the demographic aspect, namely girls are higher than boys, the social humanities study group is higher than the science and technology study group, $6^{\text {th }}$-semester students are higher than $4^{\text {th }}$-semester students, and college students scholarship awardee are higher than regular students. 
TABLE 2: Student's academic resilience capacity

\begin{tabular}{|c|c|c|c|c|c|c|}
\hline $\begin{array}{l}\text { Demographic } \\
\text { Aspect }\end{array}$ & mean & Std. Deviation & median & Mode & Min & Max \\
\hline Boy & 1.019 & 0.560 & 0.990 & 0.990 & -0.470 & 2.090 \\
\hline Girl & 1.045 & 0.580 & 0.990 & 1,250 & -0.130 & 2,760 \\
\hline $\begin{array}{l}\text { Science and Tech- } \\
\text { nology Study }\end{array}$ & 1.032 & 0.555 & 0.965 & 0.940 & -0.330 & 2,390 \\
\hline $\begin{array}{l}\text { Social Humanities } \\
\text { Study }\end{array}$ & 1.043 & 0.585 & 0.990 & 0.890 & -0.470 & 2,760 \\
\hline $4^{\text {th }}$ Semester & 0.980 & 0.617 & 0.990 & 1.040 & -0.330 & 2,760 \\
\hline $6^{\text {th }}$ Semester & 1.084 & 0.540 & 0.990 & 0.890 & -0.470 & 2,620 \\
\hline $\begin{array}{l}\text { Scholarship } \\
\text { Awardee }\end{array}$ & 1.173 & 0.625 & 0.990 & 0.300 & 0.300 & 2,760 \\
\hline Regular Student & 1.015 & 0.563 & 0.990 & 0.940 & -0.470 & 2,500 \\
\hline
\end{tabular}

To ascertain whether the difference is statistically significant, the data will be analyzed by different tests, namely ANOVA and t-test. Previously tested assumptions, the results of the normality assumption test showed that the academic resilience capacity data was classified as normal with a P-value of Shapiro-Wilk $=0.356(p>0.05)$. The results of the homogeneity assumption test show that the academic resilience capacity data is homogeneous with gender, the group of fields of study, semester level, and the status of tuition fees.

The results of the different tests using ANOVA statistical analysis showed that the differences in academic resilience capacity were not significant between genders, study groups, semester levels, and the status of tuition fees. Likewise, when exploring the difference between the father's last education, and the activeness of organizational participation on and off-campus, it was not proven that there was a significant difference. However, further exploration of the differences in academic achievement (GPA) shows that there are significant differences in terms of the father's last education, study group, and semester level. The results of the ANOVA statistical test on the difference in the last education of the father showed $\mathrm{F}=2.274 ; \mathrm{p}=0.048$; and Levene's homogeneity test $p=0.518$. GPA average scores from the highest to the most consecutive: Junior High School (3,711), Elementary school (3,706), Masters/professional degree $(3,614)$, High School and Undergraduate $(3,587)$, and Diploma $(3,469)$. Differences in the study groups are indicated by the value of $F=4021 ; p=0.046$; with Levene's homogeneity test $p=0.931$. The average value of GPA in the scientific and technology study group is 3,646 and the social humanities study is 3,584 . The difference in semester level is indicated by the value of $F=4.783 ; p=0.030$; with Levene's homogeneity test $p=0.114$. The average value of GPA in $4^{\text {th }}$ semester $(3,566)$ and $6^{\text {th }}$ semester $(3,630)$. 
TABLE 3: Empirical categories of student academic resilience capacity

\begin{tabular}{l|l|l} 
S-GPA Change & Amount & Percentage \\
\hline Decrease & 62 & $28 \%$ \\
\hline Constant & 12 & $5 \%$ \\
Increase & 147 & $67 \%$ \\
Total & 221 & $100 \%$
\end{tabular}

TABLE 4: Empirical categories of student academic resilience capacity

\begin{tabular}{lll} 
Category & Amount & Percentage \\
Very low & 7 & $3.17 \%$ \\
\hline Low & 29 & $13.12 \%$ \\
\hline Average & 150 & $67.87 \%$ \\
High & 34 & $15.38 \%$ \\
Very high & 1 & $0.45 \%$ \\
Total & 221 & $100 \%$
\end{tabular}

\subsubsection{Effect of academic resilience capacity-based on outcome-based academic resilience}

The results of the calculation of descriptive statistical analysis produce categorization based on the change of S-GPA. Students who show a decrease in S-GPA are 28\%, can maintain (constant) in S-GPA by $5 \%$, and can increase their S-GPA by $67 \%$.

In logistic regression analysis, the accuracy of the model can be seen from the omnibus test of model coefficients, the result of which is a significant model of 0.040 . The variation of students who can maintain their S-GPA or increase it is influenced by the academic resilience capacity of $2.7 \%$. Meanwhile, students with higher academic resilience capacity will have a 1.73 times chance of being able to maintain and increase their S-GPA.

\subsubsection{Effect of academic resilience capacity on academic performance}

The results of the calculation of descriptive analysis produce categorization based on empirical academic resilience capacity. Students show that they have various academic resilience capacities, ranging from very low to very high.

The results of statistical regression analysis showed that academic resilience capacity had a positive effect on academic performance (GPA) with $p<0.05$ ( $p=0.001), F=10,548$, and $R^{2}=0.046$. So the higher the academic resilience capacity, the higher the academic performance. Academic resilience provides a variation of $4.6 \%$ of academic performance. 


\section{Discussion}

Several results became the findings of this study, namely proving the effect of resilience academic capacity on academic performance, and its effect on outcome-based academic resilience. In addition, it will also explain the level of academic resilience based on capacity and outcome. The results of this study also led to an evaluation of risk factors and protective factors based on the student's subjectivity.

Students have academic resilience capacity mostly in the medium category. Thus, the average student is quite able to withstand the obstacles and difficulties they must face during the COVID-19 pandemic. (15) academic resilience exists in students if they can persevere, be reflective and seek help, and overcome negative emotions (15). The problems they face include massive changes in learning methods, economic problems, problems in the family, friendships, adjustment to the community, and personal factors. Although there are two main problems that they feel, namely, changes in learning methods and emerging economic problems, most of them are quite able to survive, still struggling quite persistently. In addition, they can also reflect that they are quite capable of meeting academic demands, by exploring evidence of previous successful experiences, as well as evaluating their needs and trying to find relevant help.

Not all students have adequate academic resilience capacity, there is a total of $16.29 \%$ which is below the average score. Thus, they are at risk of experiencing the academic consequences of the problems they experience. Based on the change in S-GPA from before the pandemic to after the pandemic, there were around $28 \%$ experienced a decrease. This condition shows that there are students who have difficulty following changes in learning methods that occur suddenly and are completely different. Students in this category can be said to have not had sufficient persistence, and the management of negative emotions has not been adaptive. In addition, they also have difficulty doing reflective and evaluation, so that the act of seeking help may not be appropriate. (37) states that in students who experience a challenge, only some can be resilient while 2/3 generally experience ongoing difficulties (37).

The next exploration is to find out what distinguishes some students who have high academic resilience capacity from those who do not. The results of the descriptive analysis show that there are differences based on gender, study program, semester level, and tuition funding status. Academic resilience capacity is higher in women, social humanities study programs, $6^{\text {th }}$-semester students (third year), and scholarship awardee. 
However, the results of the different tests did not show a statistically significant difference. This finding is different from the results of previous research studies $(9,19,31,41-$ 44). Previous research stated that there are differences in academic resilience based on differences in gender, parents' last education, and family socioeconomic status. This difference can occur because of the different points of view of academic resilience used. In the previous study, the definition used was to emphasize the outcome. Measuring the definition of outcome using value or GPA.

Academic resilience that emphasizes these outcomes is following the opinion of Gayles (2005) and Morales \& Trotman (2011), namely students who can overcome difficulties characterized by high academic achievement $(17,18)$. So based on this definition, this study also reviews the GPA of students. The results show that there are significant differences in academic achievement between groups of fields of study, semester level, and father's last education. Students have a higher GPA in the science and technology study group, $6^{\text {th }}$-semester students (third year), and father's last education in junior high school (SMP). Previous research stated that there are differences in academic resilience based on differences in gender, parents' last education, and family socioeconomic status $(9,19,31,41-44)$.

Based on the student's self-assessment, the factors that influence academic success mostly emphasize self-effort, only after that self-ability. They have the belief that if the ability is moderate, but still trying hard, then educational success can be obtained. This is proven by the results of linear regression analysis between academic resilience capacity and academic performance. The results prove that there is a significant positive effect between academic resilience capacity and academic performance. Thus, the higher the academic resilience capacity, the higher the student's academic achievement. These results are in line with research from, which proves that academic resilience influences academic achievement, but is fully mediated by the role of academic satisfaction (14).

The results of the logistic regression analysis between capacity-based academic resilience and outcome-based academic resilience (change in student's S-GPA), showed a significant positive effect between the two. The effect of capacity-based academic resilience on outcome-based academic resilience is the odds ratio of 1.73 . These results indicate that students who have high academic resilience capacity can factually achieve academic resilience, namely being able to maintain and improve academic performance by 1.73 times higher than students who have low academic resilience capacity. 


\section{Conclusion}

The results of this study indicate that academic resilience based on capacity has an important role in the smooth and successful education of college students. Academic achievement is one sign of academic resilience in students, but there are other signs, such as the ability to maintain or improve grades from previously poor to better ones, students who persist or remain in college despite facing difficult obstacles until they can graduate, can also be said to have academic resilience. It is necessary to consider during this pandemic period, students who initially did not have economic and family problems, but are currently experiencing economic problems and losing their families, then this is a risk factor for students.

Suggestions that can be given are universities and students trying to increase the capacity of academic resilience. Universities are also expected to detect student difficulties during the pandemic and provide assistance or form social support for those in need. Suggestions for further research are to use standardized and objective instruments to measure risk factors and protective factors.

\section{References}

[1] SANTROCK,W J. LIFE SPAN DEVELOPMENT 10TH EDITION. Ryan M, editor. New York: McGraw-Hill; 2020. p. 5-805.

[2] Sari J, Suhariadi F. Kontrak Psikologis terhadap Commitment to Change: Resiliensi Akademik sebagai Variabel Mediasi. Pers Psikology Indonesia. 2019;8(2):178-192. DOI: 10.30996/persona.v8i2.2535

[3] Hendriani W. Adaptasi Positif Pada Resiliensi Akademik Mahasiswa Doktoral. Humanitas (Monterey N L). 2017;14(2):139-149. DOI: http://dx.doi.org/10.26555/humanitas.v14i1.5696

[4] Fauziah, Wiyono BB, Triyono, Lasan BB. The Effect of Authoritative Parenting on the Formation of Student Academic Resilience. Int J Innov Creat Chang [Internet]. 2020;13(7):1027-37. Available from: https://www.ijicc.net/images/vol_13/Iss_7/13700u_Fauziah_2020_E_R1.pdf

[5] Thomas VF. Dampak Corona, Kadin Sebut Sudah 6 Juta Pekerja Dirumahkan \& PHK. tirto.id [Internet]. 29 May 2020. [cited 2020 Dec 20]. Available from: https://tirto.id/dampak-corona-kadin-sebut-sudah-6-juta-pekerja-dirumahkanphk-fDC7 
[6] Eva N, Parameitha DD, Farah FAM, Nurfitriana F. Academic Resilience and Subjective Well-Being amongst College Students using Online Learning during the COVID-19 Pandemic. KnE Soc Sci. 2021;4(15):202-214. DOI: 10.18502/kss.v4i15.8206

[7] Beale J. Academic Resilience and its Importance in Education after Covid-19. Et J Innov Res Educ. 2020;4(0):117. Available From: https://d1wqtxts1xzle7.cloudfront.net/64824889/ Academic_Resilience_and_its_Importance_in_Education_after_Covid_19-withcover-page-v2.pdf

[8] Perez-Brena NJ, Sang S, Kuo SIC, Rodríguez De Jesús SA, Updegraff KA, UmañaTaylor AJ, et al. Patterns of Academic Risk and Resilience: Post-High School Educational Pathways in the Context of the 2007 Economic Recession. J Adolesc Res [Internet]. 2019;34(4):351-380. Available From: 10.1177/0743558418810842

[9] Kumalasari D, Akmal SZ. Less Stress, More Satisfied in Online Learning During the COVID-19 Pandemic: The Moderating Role of Academic Resilience. Psychol Res Urban Soc. 2021;4(1):36-46. DOI: 10.7454/proust.v4i1.115

[10] Permatasari N, Rahmatillah Ashari F, Ismail N. Contribution of Perceived Social Support (Peer, Family, and Teacher) to Academic Resilience during COVID-19. Golden Ratio Soc Sci Educ. 2021;1(1):1-12. DOI: 10.52970/grsse.v1i1.94

[11] Obrad C. Constraints and Consequences of Online Teaching. Sustain. 27 August 2020;12(17):1-23.DOI: https://doi.org/10.3390/su12176982

[12] Ramadhana MR, Putra A, Pramonojati TA, Haqqu R, Dirgantara P, Ismail OA, et al. Learning Readiness as a Predictor of Academic Resilience in Online Learning during School from Home. Libr Philos Pract. May 2021;0(0):1-16. Available From: https: //digitalcommons.unl.edu/cgi/viewcontent.cgi?article=9951\&context=libphilprac\#: \$Isim\$:text=The\%20research\%20used\%20questionnaires\%20that, and\%20the\% 20academic\%20resilience\%20scale.\&text=The\%20results\%20showed\%20that\% 20there,school\%2Dfrom\%2Dhome\%20period.

[13] Meneghel I, Martínez IM, Salanova M, de Witte H. Promoting academic satisfaction and performance: Building academic resilience through coping strategies. Psychol Sch. 2019;56(6):875-890. DOI: https://doi.org/10.1002/pits.22253

[14] Cassidy S. The Academic Resilience Scale (ARS-30): A new multidimensional construct measure. Front Psychol. 2016;7(0):1-11. DOI: https://doi.org/10.3389/fpsyg.2016.01787

[15] Martin AJ, Marsh HW. Academic resilience and academic buoyancy: Multidimensional and hierarchical conceptual framing of causes, correlates and 
cognate constructs. Oxford Rev Educ [Internet]. 2009;35(3):353-370. DOI: 10.1080/03054980902934639

[16] Morales EE, Trotman FK. A focus on hope?: fifty resilient students speak. University Press of America. Plymouth, United Kingdom: University press of America; 2011. p. 101.

[17] Gayles J. Playing the Game and Paying the Pricee: Academic Resilience among Three High-Achieving African American Males. Anthropol Educ Q. 2005;36(3):250264. DOI: 10.1525/aeq.2005.36.3.250

[18] Anagnostaki L, Pavlopoulos V, Obradovic J, Masten A, Motti-Stefanidi F. Academic resilience of immigrant youth in Greek schools: Personal and family resources. Eur J Dev Psychol. 2016;13(3):377-393. DOI: 10.1080/17405629.2016.1168738

[19] Cunningham M, Corprew CS, Becker JE. Associations of Future Expectations, Negative Friends, and Academic Achievement in High-Achieving African American Adolescents. Urban Educ. May 18, 2009;44(3):280-296. DOI: https://doi.org/10.1177\%2F0042085908318715

[20] Hwang E, Shin S. Characteristics of nursing students with high levels of academic resilience: A cross-sectional study. Nurse Educ Today. 2018;71(September):54-59. DOI: 10.1016/j.nedt.2018.09.011

[21] Li H. The 'secrets' of Chinese students' academic success: academic resilience among students from highly competitive academic environments. Educ Psychol. September 2017;37(8):1001-1014. DOI: https://doi.org/10.1080/01443410.2017.1322179

[22] McGee EO, Pearman FA. Risk and Protective Factors in Mathematically Talented Black Male Students: Snapshots From Kindergarten Through Eighth Grade. Urban Educ. 2014;49(4):363-393. DOI: https://doi.org/10.1177\%2F0042085914525791

[23] Mendez JJ, Bauman S. From migrant farmworkers to first generation latina/o students: Factors predicting college outcomes for students participating in the college assistance migrant program. Rev High Educ. 2018;42(1):173-208. DOI: 10.1353/rhe.2018.0037

[24] Seçer I, Ulas S. The Mediator Role of Academic Resilience in the Relationship of Anxiety Sensitivity, Social and Adaptive Functioning, and School Refusal With School Attachment in High School Students. Front Psychol. 2020;11(557):1-12. DOI: https://doi.org/10.3389/fpsyg.2020.00557

[25] Liu B, Platow MJ. Chinese adolescents' belief in a just world and academic resilience: The mediating role of perceived academic competence. Sch Psychol Int [Internet]. 2020;41(3):1-8. DOI: 10.1177/0143034320908001 
[26] Cassidy S. Resilience building in students: The role of academic self-efficacy. Front Psychol [Internet]. 2015;6(0):1-14. DOI: 10.3389/fpsyg.2015.01781

[27] Hampton FM. The Seven Secrets of Successful Urban School Students: The Evidence Continues to Grow. Educ Urban Soc. 2016;48(5):423-443. DOl:https://doi.org/10.1177\%2F0013124514533990

[28] Martin AJ, Marsh HW. Academic resilience and its psychological and educational correlates: A construct validity approach. Psychol Sch [Internet]. 2006;43(3):267281. DOI: $10.1002 /$ pits.20149

[29] Li H, Yeung W jun J. Academic Resilience in Rural Chinese Children: Individual and Contextual Influences. Soc Indic Res [Internet]. 2017;145(2):1-15. Available From: 10.1007/s11205-017-1757-3

[30] Agasisti T, Longobardi S. Equality of Educational Opportunities, Schools' Characteristics and Resilient Students: An Empirical Study of EU-15 Countries Using OECD-PISA 2009 Data. Soc Indic Res [Internet]. 134(3):917-953. DOI: 10.1007/s11205-016-1464-5

[31] Sandoval-Hernández A, Bialowolski P. Factors and conditions promoting academic resilience: a TIMSS-based analysis of five Asian education systems. Asia Pacific Educ Rev. 2016;17(3):511-520. https://doi.org/10.1007/s12564-016-9447-4

[32] Liew J, Cao Q, Hughes JN, Deutz MHF. Academic Resilience Despite Early Academic Adversity: A Three-Wave Longitudinal Study on Regulation-Related Resiliency, Interpersonal Relationships, and Achievement in First to Third Grade. Early Educ Dev. 2018;29(5):762-779. DOI: 10.1080/10409289.2018.1429766

[33] Bronfenbrenner U. The Ecology of Human Development. London, United Kingdom: Harvard University press; 1979. p. 1-349.

[34] Linley PA, Joseph S. The Applied Positive Psychology Perspective. In: Linley PA, Joseph S, editor. Positive Psychology in Practice. New Jersey: John Wiley \& Sons; 2004. p. 1-858.

[35] Novotny JS. Academic Resilience: Academic Success as a Possible Compensatory Mechanism of Experienced Adversities and Various Life Disadvantages. New Educ Rev. 2011;23(1):91-102. Available From: https://tner.polsl.pl/e23/a6.pdf

[36] Gordon KA. Self-Concept and Motivational Patterns of Resilient African American High School Students. J Black Psychol. 1995;21(3):239-255. DOI: https://doi.org/10.1177\%2F00957984950213003

[37] Fitrah NH, Fatihah N, Madihie A. Resilience in Mathematics, Academic Resilience, or Mathematical Resilience?: An Overview. Univers J Educ Res. 2020;8(5A):34-39. DOI: 10.13189/ujer.2020.081905 
[38] Shaughnessy JJ, Zechmeister EB, Zechmeister JS. Research Methods in Psychology. Tenth Edit. New York: McGraw-Hill Education; 2015.

[39] Kumalasari D, Luthfiyanni NA, Grasiaswaty N. Analisis Faktor Adaptasi Instrumen Resiliensi Akademik Versi Indonesia: Pendekatan Eksploratori Dan Konfirmatori. J Penelit dan Pengukuran Psikol. 2020;9(2):84-95. DOI: https://doi.org/10.21009/JPPP.092.06

[40] De Feyter JJ, Parada MD, Hartman SC, Curby TW, Winsler A. The early academic resilience of children from low-income, immigrant families. Early Child Res Q. 2020;51(2020):446-641. DOI: https://doi.org/10.1016/j.ecresq.2020.01.001

[41] Wills $\mathrm{G}$, Hofmeyr $\mathrm{H}$. Academic resilience in challenging contexts: Evidence from township and rural primary schools in South Africa. Int J Educ Res. 2019;98(3):192205. DOI: 10.1016/j.ijer.2019.08.001

[42] Sandoval-Hernández A, Bialowolski P. Factors and conditions promoting academic resilience: a TIMSS-based analysis of five Asian education systems. Asia Pacific Educ Rev [Internet]. 2016;17(3):511-520. DOI: 10.1007/s12564-016-9447-4

[43] Cheung K-C, Sit P-S, Soh K-C, leong M-K, Mak S-K. Predicting Academic Resilience with Reading Engagement and Demographic Variables: Comparing Shanghai, Hong Kong, Korea, and Singapore from the PISA Perspective. Asia-Pacific Educ Res. 2014;23(4):895-909. DOI: 10.1007/s40299-013-0143-4 